\title{
More than a "touch of the flu": a response to Mayrhuber et al's "'with fever it's the real flu I would say": laypersons' perception of common cold and influenza and their differences - a qualitative study in Austria, Belgium and Croatia"
}

Annemarie Jutel ${ }^{*}$ (I)

\begin{abstract}
This short reply contests two assumptions made by the authors of Mayrhuber et al's. "With fever it's the real flu I would say." The first is that there is influenza can be reliably defined by a medical case definition. The second is that this small qualitative study can be generalisable. However, it does underline the important point that technical diagnostic terms may be used on different registers by a variety of actors in the medical setting.
\end{abstract}

Keywords: Influenza, Vaccination, Diagnosis

Elisabeth Anne-Sophie Mayrhuber and her colleagues have delved into the fascinating matter of influenza [1]. Indeed, there's probably not a more familiar pathogenic concept, if not disease. People talk about "the 'flu" with great familiarity and oft-times randomly, attributing all manner of ailments to the flu: "stomach flu" for GI upset, "a touch of the flu" for under the weather, and "man flu" for the presumed male complainer, not really ill at all.

But their article takes for granted two important assumptions that it should not have. The first is that the lay person's version should be measured against the biomedical concepts. Our work on self-diagnosis of influenza revealed that people (be they lay or health professionals) whose reported symptoms aligned with the case definition of influenza were no more likely have had influenza than those who did not [2]. And this possibly should not have surprised us. As Fabrice Carrat's team revealed in their metaanalysis, over $30 \%$ of individuals inoculated with influenza were asymptomatic even

\footnotetext{
* Correspondence: Annemarie.jutel@vuw.ac.nz

Victoria University of Wellington (NZ), Wellington, New Zealand
}

while actively shedding virus [3]. What did surprise us, however, is that the symptoms most likely to correlate with accurate self-diagnosis were runny nose and fatigue. What one should take from this is that flu is not necessarily what medicine thinks it is, so, verifying whether someone without medical education reels off features of a case definition of influenza is not necessarily helpful to diagnosis.

And, the authors should not forget that "flu" is rarely confirmed as influenza in general practice. It is explained as "flu," and charted as "influenza like illness," but the presence of the virus is not used to diagnose. The benign and self-limiting influenza infection may or may not conform to the symptom profiles that we attribute to it. Influenza infection is widely variable in its acuity and in its presentation [4], and not surprisingly, doctors, as much as lay people, resort to defining flu as being like we have always said it is, when we don't really always know [5].

The second assumption is that if lay people understand influenza better, we can improve vaccination coverage. Influenza and vaccination are different subjects and need to be differently explored. Concluding that by 
understanding a disease, a subject will necessarily want a vaccination is a leap of faith.

Qualitative research provides a deeply textured understanding of the problems faced by groups and individuals, and is indeed, useful to understanding cultural practices and beliefs. However, the information revealed by three sets of 30 individuals in different countries cannot be generalised or used, as these authors claim, as a way of increasing uptake of vaccination. On the other hand, using the material gleaned from this qualitative study, the authors could certainly devise and implement further research to determine how generalisable these views may be to the broader populations they wish to enlist in vaccination campaigns.

However, what this paper, and many like it underline, is that in any technical setting (like, in this case, medicine) lay people and technicians may use the same words, but in different registers [6, 7]. Doctors and patients alike talk about "flu" as if everyone were on the same page, when possibly the only thing they really agree on is that they are dealing about a systemic; nonspecific; and hopefully, self-limiting illness [8].

\section{Response to "more than a "touch of the flu": a response to Mayrhuber et al's "with fever it's the real flu I would say": laypersons' perception of common cold and influenza and their differences - a qualitative study in Austria, Belgium and Croatia" \\ Wim Peersman, Nina van de Kraats, Goranka Petricek, Asja Ćosić Diviak, Silvia Wojczewski and Kathryn Hoffmann}

We thank Jutel A. for her interest in our work and the addition of interesting aspects and literature to our publication [1]. We agree that our study underlines the importance of respecting that technical diagnostic terms are used on different registers by a variety of actors in the medical setting $[6,7]$.

The objective of our study was to gain a deeper understanding of individuals in Austria, Belgium and Croatia regarding their reasoning and concept in terms of common cold, influenza and its differences as well as possible cross-country differences. This is what we have elaborated and described throughout the publication.

We are in line with the comment that influenza cannot be reliably defined by a medical case definition [2, 4], which we also stated in our publication: "[...] Influenza is mainly recognized as starting with onset of a sudden high fever, whereas a common cold more commonly begins with coryza or a sore throat $[9,10]$. Although from a microbiological point of view the two diseases are clearly different from each other as distinct viruses are involved $[9,11,12]$, it may be difficult to differentiate the diseases for lay persons because they share several symptoms such as fever, cough, or limb ache. This overlap has been observed to increase the risk of confusion not only in lay persons but also in clinicians $[9,11,13]$. [...]" However, besides this challenge it is important to gain a better understanding of laypersons' reasoning and concepts of diseases to be able to pick up the individuals from their own starting points to increase communication and health literacy.

Surely, it is not enough to raise the lay person knowledge regarding influenza to improve health literacy or preventive measures like vaccination. Therefore, we discussed in addition a variety of measures like awareness activities, involvement of GPs, rapid tests as well as the use of timely epidemiological data [1]. Additionally, we agree with Jutel A. that the views collected with this sample cannot be generalized to the broader population. Namely, although the participants came from a broad range of socioeconomic backgrounds, we cannot assume that other themes would not arise in other localities and cultural groups. We clearly discussed the limitations of this qualitative study and mentioned among others the possibility for selection bias.

We welcome further research efforts to elaborate the topic further including a broader population.

\section{Acknowledgements \\ none}

\begin{abstract}
Author's contributions
I am the sole author of this correspondence. The author read and approved the final manuscript.

Author's information

Annemarie Jutel is a sociologist of diagnosis and author of Putting a Name to It: Diagnosis in Contemporary Society (JHUP) and Diagnosis: Truths and Tales (UTP). She has written broadly about influenza and self-diagnosis using both cross-sectional surveys, qualitative research methods and historical review.
\end{abstract}

Funding

I have received no funding for the preparation of this response.

Availability of data and materials

not applicable

Ethics approval and consent to participate

not applicable

Consent for publication

not applicable

Competing interests

The author declares that she has no competing interests. 
Received: 10 January 2019 Accepted: 4 September 2019

Published online: 30 October 2019

\section{References}

1. Mayrhuber EA, Peersman W, van de Kraats N, Petricek G, Cosic Diviak A, Wojczewski S, et al. "With fever it's the real flu I would say": laypersons' perception of common cold and influenza and their differences - a qualitative study in Austria, Belgium and Croatia. BMC Infect Dis. 2018;18(1):647.

2. Jutel A, Baker MG, Stanley J, Huang QS, Bandaranayake D. Self-diagnosis of influenza during a pandemic: a cross-sectional survey. BMJ Open. 2011;1(2):e000234.

3. Carrat F, Vergu E, Ferguson NM, Lemaitre M, Cauchemez S, Leach S, et al. Time lines of infection and disease in human influenza: a review of volunteer challenge studies. Am J Epidemiol. 2008;167(7):775-85.

4. Jutel A, Banister E. "I was pretty sure I had the 'flu": qualitative description of confirmed-influenza symptoms. Soc Sci Med. 2013;99:49-55.

5. Jutel A. When pigs could fly: influenza and the elusive nature of diagnosis. Perspect Biol Med. 2013;56(4):513-29.

6. Fleischman S. I am..., I have..., I suffer from... a linguist reflects on the language of illness and disease. J Med Humanit. 1999;20(1):1-31.

7. Davison C, Smith GD, Frankel S. Lay epidemiology and the prevention paradox: the implications of coronary candidacy for health education. Sociol Health IIIn. 1991;13(1):1-19.

8. Prior L, Evans MR, Prout H. Talking about colds and flu: the lay diagnosis of two common illnesses among older British people. Soc Sci Med. 2011;73(6):922-8.

9. Eccles R. Understanding the symptoms of the common cold and influenza. Lancet Infect Dis. 2005;5(11):718-25.

10. Nagata JM, Hernández-Ramos I, Kurup AS, Albrecht D, Vivas-Torrealba C, Franco-Paredes C. Social determinants of health and seasonal influenza vaccination in adults $\geq 65$ years: a systematic review of qualitative and quantitative data. BMC Public Health. 2013;13(1):388.

11. Roxas M, Jurenka J. Colds and influenza: a review of diagnosis and conventional, botanical, and nutritional considerations. Altern Med Rev. 2007;12(1):25-48.

12. Eccles R. Efficacy and safety of over-the-counter analgesics in the treatment of common cold and flu. J Clin Pharm Ther. 2006;31(4):309-19.13.

13. Call SA, Vollenweider MA, Hornung CA, Simel DL, McKinney WP. Does this patient have influenza? JAMA. 2005;293(8):987-97.

\section{Publisher's Note}

Springer Nature remains neutral with regard to jurisdictional claims in published maps and institutional affiliations.

Ready to submit your research? Choose BMC and benefit from:

- fast, convenient online submission

- thorough peer review by experienced researchers in your field

- rapid publication on acceptance

- support for research data, including large and complex data types

- gold Open Access which fosters wider collaboration and increased citations

- maximum visibility for your research: over $100 \mathrm{M}$ website views per year

At $\mathrm{BMC}$, research is always in progress.

Learn more biomedcentral.com/submissions 